] O U R A L O F

French and Francophone Philosophy
REV VUE DE LA

philosophie française et de langue française

\title{
Introduction
}

\section{The Responsibility of Awkwardness}

Nicolette Bragg

Journal of French and Francophone Philosophy - Revue de la philosophie française et de langue française, Vol XXIV, No 1 (2016) 1-8.

\author{
Vol XXIV, No 1 (2016) \\ ISSN 1936-6280 (print) \\ ISSN 2155-1162 (online) \\ DOI $10.5195 /$ jffp. 2016.754 \\ www.jffp.org
}

\section{(c) EY-NC-ND}

This work is licensed under a Creative Commons Attribution-Noncommercial-No Derivative Works 3.0 United States License.

\section{UILIS D-Sunt}

This journal is operated by the University Library System of the University of Pittsburgh as part of its D-Scribe Digital Publishing Program, and is co-sponsored by the University of Pittsburgh Press 


\title{
Introduction
}

\section{The Responsibility of Awkwardness}

\author{
Nicolette Bragg \\ Cornell University
}

The thought of the limit has in its genetics the questioning of time and place. The essays in this collection, African Thinking and/at Its Limits, demonstrate this essential interrogation (how time and space both belong to a certain critical modality); their address of (and at) the limits of African thinking confronts the potential limitedness of spatial and temporal understandings. The limit signals the very reach(es) of time and place, even as it enables the possibility of territory, control, management, and measure. Possibility itself, the very provocation of the limit, can itself be formulated in terms of time and place-What can (yet) be done? Where is it possible to go? Where do we go from here? The limit signifies both expiration, the farthest point a thinking can take one, and consolidation, the demarcation and establishment of a territory. These questions of time and place are, as such and for these very reasons, bound up in any thinking of Africa. This is clear from the themes addressed by the contributions to this collection, not the least of which are the historicity of the concepts commonly used to assess or explain state crisis, the hangovers of colonial paradigms, and the difficulty in thinking, addressing, and analyzing the crisis of the postcolony.

As each contribution examines the limitations of a common gauge of Africa, they demonstrate and foreground the interplay of time and place in relation to thinking. At issue, they engage with the failures and flaws of productions of place and the missteps of representation. Pierre-Philippe Fraiture, in this vein, addresses the dualisms that channel the persistent belief in African difference; Kasereka Kavwahirehi confronts the normativity of recent well-received counters to afropessimism (such as Patrick Chabal's and Jean-Pascal Daloz's Africa Works: Disorder as Political Instrument in Africa). At issue in almost all is the limitations of a way of thinking that flattens out, obscures, and effaces the particularities of specific places and realities. Temporality provides one avenue of rebuttal. V-Y Mudimbe's notion of "reprendre" counters the fatalism of cultural "métissage" (Fraiture), while Leopold Senghor's doubled, creative grasp of past and 
future enable his own productive formulation of assimilation (as John Drabinski shows through the 1945 essay, "Assimilation and Association"). The time and place of the limit is entangled with the time and place of African thinking, raising the question of Africa's relationship to the limit. Why are the questions of Africa so often those of the limits of thinking? What is the relevance of Africa to the thinking of the limit?

The contributions of this volume suggest that what is at stake is not only the proper place and time of thinking, but, more pertinently, the improper, and what one makes of it. Impropriety is the point of entry, for one does not dwell at the limit. (Although dwelling entails the thought of the limit, the confrontation with the limits of established accounts of place and time.) The limit is rather the place of exhaustion, depletion, uncertainty, and the threat of breakdown. The limit is the unfamiliar and the discomforting. To use the obsolete, there is something awk about thinking at the limit. Thinking at the limit takes the appearance of being, as the dictionary defines it, "directed the other way", "untoward", "out-of-theway." Awk, the thought of the limit, reorienting the question of the stranger, engages not with hospitality or transcendence, not with the extension of thought, not even with the journey or the departure, but with the way in which one's thinking calls attention to the operation of the limit. The limit, in short, is the place for and of awkwardness.

Awkwardness, rather than simply denoting a lack of skill, ease, confidence, or competence, agility or grace, is that category of belonging that calls attention to the limit. A contemporary catchword riveted to the question of time and place, awkwardness takes up the problematic of the limit. Awkwardness, in other words, is not only a manifestation of newness to or unfamiliarity of an environment, or a stilted negotiation of the rules and relationship of a place or setting, it is not simply ungainliness or gracelessness. Not directly opposed to mastery, belonging, or propriety, but recalling them nonetheless, not simply a sign of entrance, not simply unconventionality, awkwardness enables a reconsideration of the limits to arrival and accommodation.

Ta-Nehisi Coates is perhaps the most dedicated and well-known theorist of awkwardness. J.M. Coetzee, appropriately, given the kinds of difficulties his work raises, is a close second. Coates and Coetzee each write somewhat obsessively about awkwardness, countering their careful prose with the awkwardness of (their) being. Their agenda is slightly different Coates' interest in awkward is pedagogical and political; Coetzee's is ethical-but they both stipulate awkwardness not as a predicament of dispossession but as a response to social injustice. They do not bemoan or rationalize awkwardness. Awkwardness, their own or another's, is a sensible reminder of exclusion and of the conditions of being at ease. Awkwardness is, indeed, inextricably tied up for both with their shared focus on the problem of how to live in the world. Coates pursuing the racial 
injustice and the threat to black lives in the United States, Coetzee questioning the possibility of being at home in the postcolonial.

In his columns for The Atlantic, Coates builds another life for awkwardness. In these columns, he dwells on his own awkwardness, drawing upon it to critique systems of privilege. His description of his time in France with his family accentuates his awkwardness - "We hit the ground running with no time to look pretty or cool or like anything more than what we are" - and he clarifies that this is emblematic of his life - "We have bumbled into everything we've ever gotten, smacked into it sideways and awkward and shameless." 1 He litters his writing with his clumsiness. France for him is the place of "bumble", "stumble", "mishandling verbs", "fumbling pronouns", and "wrecking whole grammars." 2 Awkwardness is crucial to his assessment of how he moves through the world. He emphasizes it, as he surveys the linguistic wreckage his encounter with the phenomenon of the French language has wrought. If "the game is rigged," as he puts it, he counters not with skill or dexterity, but by way of ungainliness.

In addition, Coates defends awkwardness as the possibility of learning. Awkwardness has become the very mark of Coates' thinking. To learn and develop, he both reassuringly and exasperatedly insists, "You must have an awkward phrase."3 Awkwardness, indeed, compels thought and participates in his politics. He urges diversity for the awkwardness it generates, in this case, a necessary awkwardness that compels selfawareness: "If you are not around people who will look at you like you are crazy when you make stupid claims about other people's experiences, then you tend to keep saying stupid things about other people's experiences." 4 Stupidity, in this case, denotes a disregard for the limitations of one's own knowledge. "Better to be awkward," he ends, "than stupid." Here, the only thing that distinguishes stupidity from awkwardness is the space in which it is appears. Stupidity is the prolonged absence of the possibility of awkwardness, a willful evasion of awkwardness. Although he aligns stupidity with awkwardness - a parallel otherwise absent in his thinking he nevertheless celebrates it for what it reveals about knowledge, privilege, and learning. Awkwardness signals for Coates the exposure to a view of things that is not your own. It is the sign of an opening to one's own limitations; it is a commitment to thinking those limits. It reminds that the ease and smoothness of one's speech depends on the bounds and exclusivity of one's space. It suggests that you have let in that which disrupts the even terrain upon which it is easy not to think. Coates' is a pointed resistance to the desire for and the praise of fluidity and ease.

Coetzee's 2009 Summertime, on the other hand, builds a life out of awkwardness. ${ }^{5}$ A fictional biography of the late author J.M. Coetzee, Summertime is awkward to the extreme. It unreservedly generates and exposes awkwardness. Summertime rejects the author's prose and 
publications, and takes as its subject his life. It cuts off his body from his writing. Without writing-without mediation-that body is graceless, ungainly, and grotesque. Summertime presents the author as, in the words of the women whose stories constitute much of the work, an "automaton" (53), "disembodied" (198), not "constituted to fit into or be fitted into" (82). A title for the researched biography is suggested: "The Wooden Man." Summertime presents the author, the protagonist, as the "man dancing naked," devoid even of the constraint and control of his writing (184). Awkwardness is front and center. The author is characterized by his discomfort: "He was not at ease among people who were at ease. The ease of others made him ill at ease" (231).

Summertime foregrounds and develops a trope very familiar to Coetzee's fiction: that of the awkward, authoritative white male. Coetzee marries self-contempt to those characters able to blunder through lives founded upon colonialism." Disgrace ${ }^{6}$ and Waiting for the Barbarians ${ }^{7}$ come to mind. The desire and power of David Lurie and the Magistrate betray the narcissism of their flawed comprehension of their place in the world. Their presence is always qualified by the form of their flesh. This awkwardness the clear sense of characters of the figure they cut in their pursuits - has as a colonial backdrop. Lurie misjudges his allure and authority in postapartheid South Africa; the Magistrate looms over the body and life of a rescued prisoner girl at the outpost of empire. Rather than confession or selfindulgent criticism, Summertime reflects the nature of Coetzee's ongoing resistance to the possibility of postcolonial livability.

The focus of Summertime is the possibility of belonging. Even as Summertime relates the disconnection of its protagonist, it stresses both his love for the land (more specifically, for the Karoo farm on which he spends his boyhood) and his refusal to make any claim for belonging ("Our presence was grounded in a crime, namely colonial conquest, perpetuated by apartheid. Whatever the opposite is of native or rooted, that was what we felt ourselves to be," his colleague relates (210)). Awkwardness, Summertime suggests, is the only recourse of the colonialist inhabiting the postcolony. To be awkward is to be neither host nor guest. It is to be neither master nor stranger. It is to fail at belonging, persistently. Coetzee makes of awkwardness an ethics, a mode of being that registers non-belonging in one's home, that resists any claim to ease or space. He establishes awkwardness as a resistance to and condemnation of belonging. Awkwardness is the utterly humorless reflection on the fragile fabrication of one's belonging. This is Coetzee's ethical stance, the only being-with he allows himself: to be ill at ease with the ease of others.

Although they do so from different perspectives, Coates and Coetzee each examine the responsibility of awkwardness, or the awkwardness of responsibility. For Coetzee, awkwardness emerges as a non-exclusive assertion of presence or accounting for presence. For Coates, awkwardness 
adjudicates not presence, but the accepted measures and bounds of place. Coates and Coetzee give to the social concern of awkwardness - the societal question of etiquette, embarrassment, conformity - a political resonance and relevance.

This, given the theoretical potential of awkwardness, is not surprising. Awkwardness depends on a prescribed narrative or program, a sense of how things should be. Awkwardness measures the relationships between things and people. It asserts the importance of the question of how to be part of a community, of how to be among others. Awkwardness depends on the limits of a space, of its confinement. Its appearance reminds of these limits. Indeed, awkwardness is the break that calls attention to the contingency of the rules. Awkwardness raises awareness of often ignored spaces between objects and people, glaring gaps that upset the rhythm of words, that trip tongues and steps. It recognizes that the world looms differently around each of us. Awkwardness is simply a non-conformance to the established alignment of time and space. Theorizations of awkwardness makes being at ease suspect. It raises the question of what might be missing. The absence of awkwardness triggers the question of exclusion. Hence the urgency of thinking and critique, the need to both risk and create awkwardness that might demonstrate the shortfalls and errors of apprehensions of place.

Awkwardness denotes a moving among, but with a slight tilt or bend. The awkward body seems new to a space, as if they have not been together much. To be awkward is to be moving in a world slightly to the side of the one in which everyone else operates. There is a time lag. It is movement at a slightly different tempo. It is the sign of a disconnection from an apprehension of place and time that signals and shows the contingency of this connection and its potential exclusivity. Moreover, awkwardness gestures to the possibility of an unexamined connection, an unconventional alignment of time and space. Awkwardness, in other words, is simply a nonconformance to the accepted alignment of time and place. Employed to signal social ineptitude, the theoretical potential and the conditions of awkwardness highlights the way in which the limit calls itself into question, interrupting the patterns and habits and thought that lead to its establishment. Awkwardness then does have a relationship to both ethics and thought. Awkwardness calls into question the smooth fit of time and place. At its most promising, as a readjustment of time and place, awkwardness is thought.

Each of the essays of this volume inclines to the production of awkwardness. Engaging with pressing issues of livability whose address continues to be stymied with by now haggard colonial conceptual baggage, as well as with current debates in African philosophy and politics, these essays are attuned to the difficulties of thinking any place and of the distrust that should accompany any attempt that proceeds too easily. They raise hills, create friction, and destabilize terrain in order to call attention to the 
problems of popular, often skilled discourses of Africa. These essays jam the fluency of discourses about Africa, calling attention to what such discourse must flatten out or ignore in order to flow. Whether it is to call attention to the myopia of the Failed States Index (Abushar)-Sudan, one of the awkward states, calls attention to the exertions, contingencies, and interdependencies of sovereignty and survival-or to the blindness of intellectually popular theories of African society to their own ideological foundations (Kavwahirehi, Olúfémi Táíwò), they set the stage for awkwardness, the first, necessary sign of thinking that marks an entrance into the situations we address. They interrupt, in other words, complacent thinking that sets the terrain even as it navigates it.

This is evident in Fraiture's reading of V-Y. Mudimbe's "Rependre: Enunciations and Strategies in Contemporary African Arts," bracketed between an analysis of the Présence Africaine-commissioned 1953 documentary Les Statues meurent aussi and its 2013 reprisal, video artist Duncan Campbell's It for Others. The constellation shows the persistence of colonial paradigms of Africa dependent on notions of difference, homogeneity, and uniqueness, all of which view any change or transformation in cultural production as its death. Mudimbe's "Rependre" articulates a mode of productive influence-a re-appraisal, a reprisal according to context-that "disrupt[s] the rigid historicity (pre-colonial, colonial, post-colonial) that for a very long time prevailed among scholars of European imperialism and art historians" and that upsets the dualisms that governed thought on African art.

The concerns of Richard Pithouse's essay are precisely those that provoke Coetzee's and Coates' insistence on awkwardness. Pithouse engages with the philosophical dimensions of praxis, and with the political situation that prohibits the social organization and interaction that would enable the "future-oriented politics" his essay invokes and turns toward. A key issue is the alienation of intellectuals and academics from popular struggles and the liberal restriction of reason. Pithouse, however, draws on the thinker who blows the question of awkwardness out of the water. Franz Fanon dispenses with the thought of awkwardness as he makes of the limit the realm in which one thinks and is. It is perhaps for this reason that the continued relevance of Fanon, as Pithouse argues, marks the "limit to political thought," indicative as this relevance is of the absence of "a compelling emancipatory vision" fifty years after his death. The limit calls for Fanon and recalls Fanon. To transcend Fanon, to transcend the limit, one must take him "seriously."

Jean-Paul Martinon provides another view of ethical awkwardness. An awkward ethics is a commitment to the apprehension of the stabilizations and exclusions that attend speech. "Between Earth and Sky" examines the mono-logic time of the thinking " $\mathrm{I}$ " that inevitably objectifies Africa, relegating it to " $a$ single time with $a$ past and $a$ future." To resist this mono- 
logic, Jean-Paul Martinon writes his essay as an address to Africa: "Africa, who are you?" It is an address that turns the conversation away from one's own comfort. "Between Earth and Sky" turns to the post-philosophy of Ivorian Bourahima Ouattara to de-center the "I" of thought. Ouattara's reprisal of Martin Heidegger's fourfold relates thinking to dwelling, a term that does not designate home or house but that nevertheless depends upon their relation to situatedness and place. Presenting thought as dwelling situates the otherwise central "I" as merely one among gods, earth, and sky. The address, although it resembles Derrida's questioning of the stranger, is not precisely a gesture of hospitality. It marks rather the departure from home, the entrance into dwelling that encompasses not only one's own "apprehension in time-place" but the extensions and limits of earth and sky and the unanticipated, unpredictable appearances of the gods.

Martinon's address un-writes the authority of the essay, disclaiming its origination in the author. Awkwardness is the question of the privilege of participation, the inevitable betrayal of any speech, the violent inscriptions of language. It is a refusal to be at ease and an openness to discomfort. Awkwardness reminds of the contingency of belonging and the work of the limit. As such, it has its own poetics, a gentle, but insistent, impropriety. An awareness and rejection of the temporality of the game, rather than simply its rules. Only superficially a sign of mistiming and unfamiliarity, awkwardness is that thinking that encapsulates the rewards and risks of the limit: the risk of discomfort, the promise of thinking, the disruption of complacency. The contributions to this volume risked the promise of thinking without effacing the discomfort of awkwardness. The agility and generosity of their thought, their accommodation, provide the time and space in which to think. They allow even the space to be awkward. It is, in the end, the space of the possible.

1 Coates, Ta-Nehisi. "The Most Dangerous Thing in America: a Brother with a Passport." The Atlantic. Jul. 10, 2013.

${ }^{2}$ Coates, Ta-Nehisi. "Privilege is Like Money: Reflections From France." The Atlantic. Jul. 6, 2013. http://www.theatlantic.com/international/archive/2013/07/privilege-is-like-moneyreflections-from-france/277559/

${ }^{3}$ Coates. “Neal Brennan-White America's Greatest Klingon Writer.” The Atlantic. 17 Jan. 2014. http://www.theatlantic.com/entertainment/archive/2014/01/neal-brennan-white-americasgreatest-klingon-writer/283172/

${ }^{4}$ Coates. "To stop Being the Party of Stupid You Must Stop Being Stupid." The Atlantic. Jun. 12, 2013. http://www.theatlantic.com/politics/archive/2013/06/to-stop-being-the-party-of-stupidyou-must-stop-being-stupid/276804/ 
${ }^{5}$ Coetzee, J.M. Summertime. New York: Penguin Books, 2009.

${ }^{6}$ Coetzee, J.M. Disgrace. New York: Penguin Books, 2000.

${ }^{7}$ Coetzee, J.M. Waiting for the Barbarians. New York: Penguin Books, 1982. 